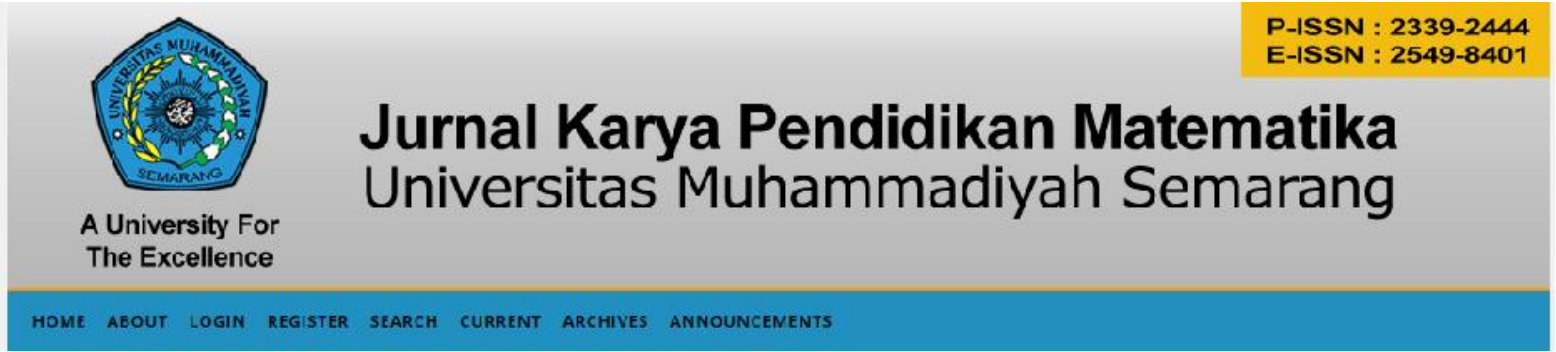

\title{
PENGARUH KEAKTIFAN DAN MINAT TERHADAP HASIL BELAJAR SISWA POKOK BAHASAN TRIGONOMETRI MELALUI MODEL PEMBELAJARAN BERBASIS MASALAH DI KELAS XSMA 15 SEMARANG
}

\author{
Oleh: Sri Wigati \\ dra.wigati@gmail.com \\ SMA Negeri 15 Semarang
}

\begin{tabular}{ll}
\hline \multicolumn{3}{l}{ Article history } \\
\hline Submission & $: 10 / 9 / 2018$ \\
Revised & $:$ \\
Accepted & $: 20 / 9 / 2018$
\end{tabular}

Keyword:

activeness, interest,

problem-based learning.

\begin{abstract}
Student's enthusiasm and interest in learning mathematics are factors that influence learning outcomes. Where in the application of problembased learning models on trigonometric material that aims to improve learning outcomes, but in the application process will also appear the activeness of students during the learning process takes place. This is intended to supplement the problem-based learning process in stages, including: understanding the problem, making a solution plan, implementing the plan, and reviewing the results obtained. From these stages there will also appear student activity and interest in the mathematics learning process which certainly contributes to learning outcomes. So the purpose of the study is to determine the effect of activeness and interest in student learning outcomes on trigonometry subjects through problem-based learning models. This research was designed using the One-Shot Case Study design. In this design there is only one group treated. The population in this study were all students of SMA Negeri 15 Semarang. With the sampling technique in this study using the Random sampling technique, obtained a sample of students in class X 7. The variables used are the activeness and interest of students and are learning outcomes. The results of the study concluded that there was a significant influence between activity and interest in learning outcomes with a significant effect of $81.8 \%$ in the implementation of $\mathrm{pr}$

oblem-based learning models.
\end{abstract}

\section{Pendahuluan}

Hasil belajar merupakan kemampuan siswa setelah memperoleh pengalaman belajar. Hasil belajar mempunyai peranan penting dalam proses pembelajaran karena akan memberikan sebuah informasi kepada guru tentang kemajuan siswa dalam upaya mencapai tujuan-tujuan belajarnya melalui proses kegiatan belajar mengajar, setelah mendapat informasi tersebut guru dapat menyusun dan membina kegiatan-kegiatan siswa lebih lanjut baik untuk individu maupun kelompok belajar. Pengalaman belajar yang diperoleh tentunya mencakup aspek kognifit, aspek afektif dan aspek psikomotorik. Hal ini juga diperkuat 
dengan Permendikbud Nomor 23 tahun 2016 tentang standar penilaian pendidikan, dimana pada pasal 3 menyebutkan bahwa penilaian hasil belajar siswa pada pendidikan dasar dan pendidikan menengah meliputi aspek : sikap, pengetahuan dan keterampilan. Sehingga pada proses pembelajaran tentunya tidak hanya sekedar aspek pengetahuannya saja yang diukur namun aspek sikap dan keterampilan menjadi faktor penting pula. Hal tersebut tentunya diperuntukkan bagi semua mata pelajaran. Termasuk didalamnya mata mepajaran matematika.

Pada implementasi proses pembelajaran matematika tentunya terdapat berbagai faktor yang mempengaruhi hasil belajar. Seperti yang dikemukakan oleh Munadi (Rusman, 2012) bahwa faktor-faktor yang mempengaruhi hasil belajar antara lain meliputi faktor internal dan faktor eksternal. Faktor internal antara lain : (a) faktor fisiologis, dimana kondisi umum seperti kesehatan yang prima dan kesehatan jasmani akan mempengaruhi siswa dalam menerima pengetahuan yang dipelajari dan (b) faktor psikologis, meliputi IQ, perhatian, minat, bakat, motivasi dan daya nalar. Faktor eksternal meliputi lingkungan dan instrumental.

Hasil analisis kegiatan pembelajaran matematika di SMA Negeri 15 Semarang pada siswa kelas $\mathrm{X}$, diperoleh bahwa guna meningkatkan hasil belajar siswa dalam materi trigonometri, maka diterapkan model pembelajaran berbasis masalah. Hal ini dikarenakan model pembelajaran berbasis masalah memberikan cara belajar dimana siswa dihadapkan pada suatu masalah yang autentik sehingga siswa dapat menyusun pengetahuan mereka sendiri, mengembangkan inkuiri dan keterampilan berpikir tingkat lebih tinggi, mengembangkan kemandirian dan percaya diri, dan dapat menyusun pengetahuan mereka sendiri tentang dunia sosial dan sekitarnya (Saiadi, 2014).

Berikut langkah-langkah yang pembelajaran berbasis masalah menurut Polya (Erniwati, 2011) yang dilakukan dalam penelitian ini adalah sebagai berikut:

1. memahami masalahnya. Apa saja yang diketahui, apa yang tidak diketahui dan apa syarat-syaratnya;

2. membuat rencana pemecahan: mencari hubungan antara yang diketahui dengan yang tidak diketahui. Apakah hal tersebut pernah diketahui dan adakah kaitannya dengan masalah tersebut;
3. melaksanakan rencana tersebut. Memeriksa setiap langkahnya. Apakah setiap langkahnya benar dan apakah dapat dibuktikan bahwa hal tersebut benar;

4. memeriksa kembali. Menyelidiki penjelasan yang dilakukan. Mengecek hasilnya. Apakah dapat dicek alasan dan jalan pikirannya, apakah dapat diperoleh jawaban dengan cara yang lain dan apakah hasilnya atau metodenya dapat digunakan pada masalah yang lain.

Dalam menerapkan pembelajaran berbasis masalah tersebut tentunya dikaitkan dengan matematika dalam kehidupan seharihari, sehingga dengan begitu antusias minat siswa belajar matematika akan muncul. Berdasarkan analisis masalah dan teori dalam penerapan pembelajaran berbasis masalah tersebut, maka tujuan penelitian ini adalah guna mengetahui besar pengaruh keaktifan dan minat terhadap hasil belajar siswa pokok bahasan trigonometri melalui model pembelajaran berbasis masalah.

\section{Metode Penelitian}

Penelitian ini merupakan penelitian One-Shot Case Study (Sugiono, 2012), yaitu penelitian yang memberikan perlakuan pada suatu kelompok. Kelompok yang dimaksud dalam penelitian ini adalah siswa kelas X SMA Negeri 15 Semarang dengan menggunakan teknik Purpossive Sampling sampel diperoleh kelas X-7 SMA Negeri 15 Semarang sebagai sampel dalam penelitian ini. Selanjutnya sampel diberi perlakuan yaitu implementasi model pembelajaran berbasis masalah.

Variabel bebas dalam penelitian ini adalah keaktifan dan minat belajar siswa. Sedangkan variabel terikatnya adalah hasil belajar. Data yang didapat diperoleh dari : (a) observasi, digunakan untuk mengetahui keaktifan siswa dalam pembelajaran, (b) angket, digunakan untuk mengetahui minat belajar siswa, (c) tes, digunakan untuk mengetahui prestasi belajar siswa, dan (d) dokumentasi, digunakan untuk mendokumentasikan hasil penelitian.

Instrumen yang digunakan dalam penelitian ini adalah :

(a) instrument tes digunakan untuk mengukur hasil belajar siswa aspek kognitif dengan indikator pencapaian :

Tabel 1. Indikator Hasil Belajar

No Indokator

59

http://jurnal.unimus.ac.id/index.php/JPMat/index 
1 Menyelesaikan perhitungan soal menggunakan aturan sinus.dan cosinus.

2 Dapat bekerjasama dengan siswa lain dalam menyelesaikan perhitungan soal cerita yang berkaitan dalam kehidupan sehari-hari menggunakan aturan sinus dan cosinus.

(b) Instrumen non tes digunakan untuk mengukur kekaktifan dan minat belajar siswa menggunakan skala likert. Dimana alat yang diukur untuk mengetahui keaktifan siswa menggunakan embar observasi sedangkan alat ukur yang diguankan untuk mengetahui minta siswa adalah lembar angket minat siswa dalam proses pembelajaran berbasis masalah.

Berdasarkan tujuan penelitian yaitu mengetahui pengaruh keaktifan dan minat terhadap hasil belajar, maka analisis data yang digunakan adalah uji Regresi Linear Ganda. Analisis data tersebut menggunakan SPSS 17. Berikut langkah analisis yang dilakukan : (1) uji normalitas data hasil belajar sebagai uji prasyarat, (2) uji regresi linear ganda, (3) melihat nilai $\mathrm{r}$ square untuk mengetahui seberapa besar pengaruh keaktifan dan minat terhadap hasil belajar.

\section{Hasil Penelitian dan Pembahasan}

Dalam penelitian ini instrument yang digunakan berupa tes hasil belajar materi trigonometri dan observasi keaktifan diasumsikan dalam keadaan valid dan reliable sehingga instrument dapat digunakan dalam pembelajaran yang menerapkan model pembelajaran berbasis masalah pada pokok bahasan trigonometri.

Tabel 2 Uji Normalitas Data

One-Sample Kolmogorov-Smirnov Test

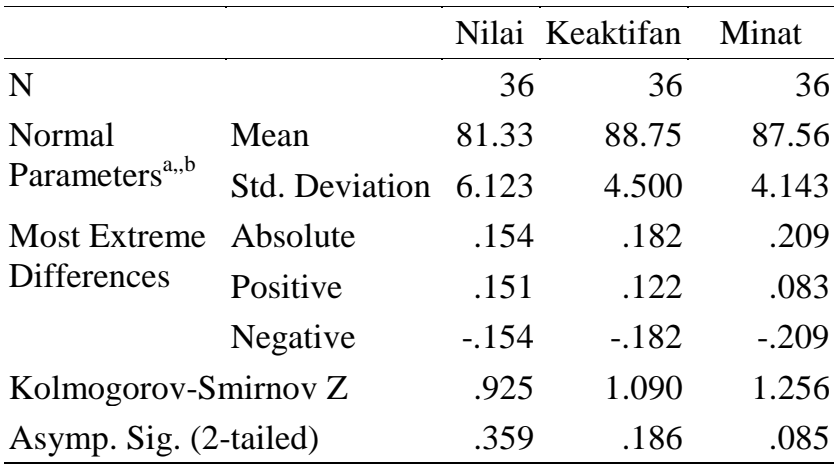

a. Test distribution is Normal.

b. Calculated from data.

Hasil tabel di atas menunjukkan bahwa nilai signifikansi untuk hasil belajar sebesar $0,359>5 \%$, sedangkan signifikansi data keaktifian sebesar 0,186>5\% dan siginfikansi data minat sebesar $0,085>5 \%$. Jadi dapat dikatakan bahwa data nilai hasil belajar, keaktifan dan minat berdistribusi normal.

Tahap selanjutnya adalah uji regresi linear ganda. Tujuannya adalah untuk mengetahui adanya pengaruh keaktifan (variabel X1) dan minat (variabel X2) terhadap hasil belajar siswa (variabel Y) dan jika ada pengaruhnya seberapa besarkah pengaruh tersebut. Dalam uji regresi langkah awal yang dilakukan adalah uji keberartian terlebih dahulu. Berikut hipotesis dan hasil analisis data yang menggunakan SPSS 17.

$H_{0}: b_{1}=0$ (tidak ada pengaruh kekatifan dan minat terhadap hasil belajar).

$H_{1}: b_{1} \neq 0$ (ada pengaruh kekatifan dan minat terhadap hasil belajar).

Kriteria : terima $H_{0}$ jika nilai signifikan $>5 \%$ dengan taraf signifikan yang ditetapkan peneliti sebesar 5\%. Untuk mengetahui nilainya dapat dilihat pada tabelberikut.

Tabel 3. Uji Keberartian

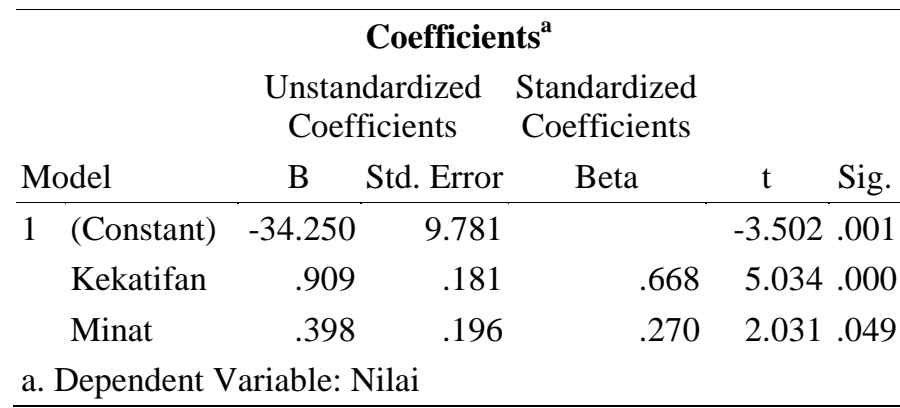

Berdasarkan hasil analisis pada tabel di atas diperoleh nilai Sig. pada keaktifan sebesar $0,00<5 \%$ dan Sig. pada minat sebesar $0,049<$ 5\% sehingga $\mathrm{H}_{1}$ diterima. Jadi terdapat pengaruh keaktifan dan minat terhadap hasil belajar. Persamaan regresi : $\hat{Y}=a+\mathrm{bX} 1+\mathrm{cX} 2$ Berdasarkan tabel di atas diperoleh persamaan $\hat{Y}=-34,250+0,909 \mathrm{X} 1+0,398$ X2. Tahap selanjutnya adalah uji kelinearan.

Uji kelinieran adalah untuk mengetahui kebenaran persaman $\hat{Y}=-34,250+0,909 \mathrm{X} 1+$ $0,398 \times 2$ adalah persamaan linear. Berikut hipotesis untuk menguji kelinieran :

$H_{0}: \beta=0$ (persamaan regresi tidak linier)

$H_{1}: \beta \neq 0$ (persamaan regresi linier)

Kriteria : terima $H_{0}$ jika nilai signifikan $>5 \%$ dengan taraf signifikan yang ditetapkan peneliti sebesar 5\%. Untuk mengetahui nilainya dapat dilihat pada tabel ANOVA dibawah ini. 
Tabel 4. Uji Kelinearan

\begin{tabular}{|c|c|c|c|c|c|c|}
\hline \multicolumn{7}{|c|}{ ANOVA $^{b}$} \\
\hline \multicolumn{2}{|c|}{ Model } & $\begin{array}{l}\text { Sum of } \\
\text { Squares }\end{array}$ & df & $\begin{array}{l}\text { Mean } \\
\text { Square }\end{array}$ & $\mathrm{F}$ & Sig. \\
\hline \multirow[t]{3}{*}{1} & Regression & 1073.364 & 2 & 536.682 & 74.215 & $.000^{\mathrm{a}}$ \\
\hline & Residual & 238.636 & 33 & 7.231 & & \\
\hline & Total & 1312.000 & 35 & & & \\
\hline
\end{tabular}

a. Predictors: (Constant), Minat, Kekatifan

b. Dependent Variable: Nilai

Berdasarkan tabel ANOVA di atas diperoleh nilai Sig. $=0 \%<5 \%$, sehingga tolak $H_{0}$ dan terima $H_{1}$ artinya persamaan regresinya adalah linier. Untuk mengetahui besar pengaruh kekatifan dan minat belajar terhadap hasil belajar siswa dalam penerapan pembelajaran berbasis masalah dapat dilihat pada model summary tabel R square.

Tabel 5. Besar Pengaruh

\section{Model Summary}

\begin{tabular}{|c|c|c|c|c|}
\hline $\begin{array}{l}\text { Mode } \\
1\end{array}$ & $\mathrm{R}$ & $\begin{array}{c}\mathrm{R} \\
\text { Square }\end{array}$ & $\begin{array}{l}\text { Adjusted R } \\
\text { Square }\end{array}$ & $\begin{array}{l}\text { Std. Error of the } \\
\text { Estimate }\end{array}$ \\
\hline 1 & $.904^{\mathrm{a}}$ & .818 & .807 & 2.689 \\
\hline
\end{tabular}

Berdasarkan tabel model summary diperoleh nilai $R^{2}=0,818=81,8 \%$ artinya hasil nelajar siswa dipengaruhi oleh keaktifan dan minat sebesar $81,1 \%$ dan $18,9 \%$ dipengaruhi faktor lain. Hal ini artinya kekatifan dan minat belajar siswa dalam penerapan pembelajaran berbasis masalah keduanya bersamaan memberikan kontribusi pengaruh yang besar secara signifikan.

Besar pengaruh tersebut dikarenakan adanya penerapan pembelajaran berbasis masalah yang dikaitkan dengan kehidupan sehari-hari. Siswa tentunya sangat tertarik dengan pembelajaran matematika yang dapat diimplentasikan dengan kehidupan nyata apalagi dalam materi trigonometri, yang sering kali siswa takut dengan materi tersebut karena merisi dengan perbandingan sudut sinus, cosinus, tangen, dll. Dan juga banyak konsep terkait materi trigonometri. Namun dengan adanya pembelajaran berbasis masalah trigonometri dalam kehidupan sehari-hari membuat mereka mengetahui manfaat trigonometri dalam bidang lain. Hal ini juga sejalan dengan tujuan mata pelajaran matematika berdasarkan Depdiknas (dalam Effendi, 2012) untuk semua jenjang pendidikan dasar dan menengah adalah agar peserta didik mampu: (1) Memahami konsep matematika, menjelaskan keterkaitan antarkonsep, dan mengaplikasikan konsep atau algoritma secara luwes, akurat, efisien, dan tepat dalam pemecahan masalah, (2) Menggunakan penalaran pada pola dan sifat, melakukan manipulasi matematika dalam membuat generalisasi, menyusun bukti, atau menjelaskan gagasan dan pernyataan matematika; (3) Memecahkan masalah yang meliputi kemampuan memahami masalah, merancang model matematika, menyelesaikan model, dan menafsirkan solusi yang diperoleh; (4) Mengkomunikasikan gagasan dengan simbol, tabel, diagram, atau media lain untuk memperjelas keadaan atau masalah; dan (5) Memiliki sikap menghargai kegunaan matematika dalam kehidupan, yaitu rasa ingin tahu, perhatian, dan minat dalam mempelajari matematika, serta sikap ulet dan percaya diri dalam pemecahan masalah.

Implementasi pembelajaran berbasis masalah, siswa dituntut untuk berpikir lebih kreatif dalam menyelesaikan masalah. Hal ini membuat siswa akan berusaha lebih untuk menyelesaikan permasalahan tersebut. Melalui berpikir kreatif dan dengan usaha yang lebih dibandingkan pembelajaran konvensional membuat hasil belajar siswa meningkat. Selain itu dengan minat siswa yang tinggi terhadap pembelajaran berbasis masalah, dapat berpengaruh terhadap hasil belajar siswa hal ini sesuai dengan pernyataan Nasution (2010) yaitu minat akan mempengaruhi kegiatan individu untuk mencapai segala sesuatu yang diinginkan dalam segala tindakan.

\section{Simpulan dan Saran}

Simpulan

Berdasarkan hasil penelitian dan pembahasan yang diuraikan, diperoleh simpulan sebagai berikut :

1. Keaktifan dan minat belajar berpengaruh signifikan terhadap hasil belajar siswa kelas $X$ IPA SMA negeri 15 Semarang dalam pelaksanaan pembelajaran berbasis masalah.

2. Besar pengaruh keaktifan dan minat terhadap hasil belajar dalam pembelajaran berbasis masalah adalah sebesar $81,8 \%$. 
Saran

Saran yang dapat diberikan dalam pelaksanaan pembelajaran berbasis masalah adalah perlu adanya simulasi terlebih dahulu sebelum dilakukan pada kelas eksperimen. Sehingga pada pertemuan pertama siswa sudah terkondisikan untuk penerapan pembelajaran berbasis masalah.

\section{Daftar Pustaka}

Effendi, L. (2012). Pembelajaran Matematika Dengan Metode Penemuan erbimbing Untuk Meningkatkan Kemampuan Representasi Dan Pemecahan Masalah Matematis Siswa SMP. Jurnal Penelitian Pendidikan. 13(2): 2

Erniwati. (2011). Upaya Meningkatkan Kemampuan Pemecahan Masalah Matematika Siswa Kelas VIII SMP Negeri 2 Depok Dengan Menggunakan LKS Berbasis PMR Melalui Model Pembelajaran Kooperatif Tipe STAD Pada Pokok Bahasan Panjang Garis Singgung
Lingkaran. Skripsi. Program Studi Pendidikan Matematika Universitas Negeri Yogyakarta.

Nasution. (2010). Berbagai Pendekatan dalam Proses Belajar dan Mengajar. Cetakan keduabelas. Bumi Aksara. Jakarta.

Peraturan Menteri Pendidikan dan Kebudayaan RI Nomer 23 Tahun 2016 Tentang Standar Penilaian Pendidikan.

Rusman. (2012). Belajar dan Pembelajaran Berbasis Komputer Mengembangkan Profesionalisme Guru Abad 21. Bandung: ALFABETA.

Sariadi, Ni Ketut. Pudjawan, Ketut. Syahruddin, H. (2014). Penerapan Pembelajaran Berbasis Masalah untuk Meningkatkan Hasil Belajar IPA Kelas V SD. E-journal MIMBAR PGSD Universitas Pendidikan Ganesha. Vol 2. Nomer 1. Sugiyono. (2012). Metode Penelitian Pendidikan. Bandung: Alfabeta. 